УДК 37.015.31:7:784(477)

DOI:

Оксана Бобечко, кандидат мистецтвознавства, доцент кафедри народних музичних інструментів та вокалу Інституту музичного мистеитва Дрогобицького державного педагогічного університету імені Івана Франка Любов Бонис, студентка магістратури Інституту музичного мистецтва Дрогобицького державного педагогічного університету імені Івана Франка

\title{
УКРАЇНСЬКІ НАРОДНІ ДУМИ В СУПРОВОДІ КОБЗИ-БАНДУРИ ЯК ДЖЕРЕЛО МУЗИЧНО-ЕСТЕТИЧНОГО ВИХОВАННЯ ПІДРОСТАЮЧОГО ПОКОЛІННЯ
}

Статтю присвячено дослідженню проблеми музично-естетичного виховання підростаючого покоління на високохудожніх вокально-інструментальних зразках, якими є епічні твори, зокрема українські народні думи в супроводі кобзи-бандури. Особливу увагу в розвідиі приділено процесу вивчення думового епосу иколярами на уроках музичного мистецтва, а також висвітленню виконавського мистецтва кобзарів, які, незважаючи на всі заборони і переслідування, у всі часи пропагували загальнолюдські ичінності та національні українські традииії.

Ключові слова: кобза; бандура; бандурне мистецтво; епічний репертуар; думи; музично-естетичне виховання.

תim. 7.

Oksana Bobechko, Ph.D.(Art Study), Associate Professor of the Folk Musical Instruments and Vocals Department Institute of Music Art Drohobych Ivan Franko State Pedagogical University Lyubov Bonys, Master Student at the Institute of Music Arts Drohobych Ivan Franko State Pedagogical University

\section{UKRAINIAN FOLK DUMAS ACCOMPANIED BY KOBZA-BANDURAAS A SOURCE OF MUSICALAND AESTHETIC EDUCATION OFTHE UPCOMING GENERATION}

The article is devoted to the study of the problem of musical and aesthetic education of the upcoming generation based on highly artistic vocal-instrumental samples, which are epic works, namely, Ukrainian folk dumas accompanied by kobza-bandura, which became an irreplaceable part of the musical genre attribute of the kobza players. It states that the vocal-instrumental art of folk performers has always had a significant impact on musical and aesthetic education and upbringing, since their social and professional activities, despite all prohibitions and persecutions, have always been aimed at awakening the consciousness of the Ukrainian people, preservation and further development of its cultural heritage, propagation of Christian faith and high morals, love for people, native land, as well as being demanding to one's repertoire and performance. The article notes that in modern educational reform considerable attention is being paid to the musical and aesthetic upbringing of the young generation, which aims at expanding the spiritual world, forming an emotional sphere, developing a sense of beauty, and improving musical taste. The leading role in the modern process of musical and aesthetic education of school youth in Ukraine is played by a teacher of music, whose work is a musical and aesthetic center in a public school. The true education of the child should be based first and foremost on the cultural and historical values of his or her nation; therefore special attention is paid to the process of studying the duma epos works by school students during musical art lessons. The authors note that the Ukrainian folk dumas belonging to the unique heritage of the world's epic traditional culture preserve and convey the sacramental culture of our people, reproduce its cultural and historical values, are the best help to form the high moral qualities and national-patriotic feelings of the upcoming generation.

Keywords: kobza; bandura; bandura art; epic repertoire; Dumas; musical aesthetic education.

$\Pi$ остановка проблеми. У сучасній педагогічній науці актуалізується та иділяється окрема галузь етнопедагогіка, яка досліджує конкретні етнічні традиції виховання. В цьому контексті, викристалізуваний в Україні протягом віків педагогічний досвід народу, втілений в його мудрості, вміннях і навичках для виховання наступних поколінь має вагоме значення. Він відображений у фольклорі, іграх, танцях, у мистецьких творах, обрядах та традиціях, які будять розум, спонукають замислитися над 


\section{УКРАЇНСЬКІ НАРОДНІ ДУМИ В СУПРОВОДІ КОБЗИ-БАНДУРИ ЯК ДЖЕРЕЛО МУЗИЧНО-ЕСТЕТИЧНОГО ВИХОВАННЯ ПДРОСТАЮЧОГОПОКОЛІННЯ}

невідомими явищами, почуттями та переживаннями людей. Українська етнопедагогіка, яка довгий час перебувала у стагнації, за теперішніх умов стає основою розвитку національної культури й духовності. Важливою також є її роль в музичноестетичному вихованні підростаючого покоління, яке повинно спиратися на глибокі українські традиції та відповідати вимогам часу. "У підготовці молоді до життя і праці, їі гармонійного розвитку, велику роль відіграли в минулому і продовжують відігравати у наш час традиції

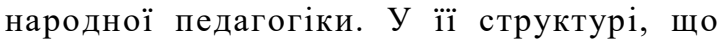
представляє сукупність емпіричних знань у справі виховання, значне місце посідає музична етнопедагогіка" [3, 4] - справедливо зауважив професор М. Вовк. Беззаперечним є той факт, що на формування музично-естетичного виховання сучасної шкільної молоді має вплив вивчення високохудожніх мистецьких творів, до яких, безумовно, можна віднести національні епічні жанри. Думи, балади, канти, псалми, історичні пісні, виконувані народними кобзарямибандуристами, свого часу впливали на почуття i розум українців і виховували в них духовність, патріотизм і любов до України, народу, рідної мови. Відтак, потребує постійного і глибокого вивчення кобзарська творчість, як джерело сучасного бандурного виконавства та важливий аспект національної ідентичності та самоутвердження українців.

Історіографія нашого народу передана в літописах, аналогом яких в народному музичному мистецтві стали думи - основа вокальноінструментального репертуару бандуристів. Збагативши звукову палітру народного мистецтва, бандурне виконавство відобразило у епічних мистецьких образах дум фундаментальні риси менталітету українців. Проте, в науці не достатньо досліджувалася проблема музичноестетичного виховання підростаючого покоління на високохудожніх вокально-інструментальних зразках, якими $\epsilon$ епічні твори.

Мета статті полягає у виявленні впливу епічного репертуару, зокрема - дум, на музично-естетичне виховання школярів.

Огляд останніх досліджень і публікацій. Грунтовне дослідження українського думного епосу знайшло відображення в монографіях Ф. Колесси, К. Грушевської, С. Грици, Г. Нудьги, Д. Ревуцького. В цих працях автори пропонували детальний аналіз епічної складової репертуару кобзарів, їх виконавської специфіки, регіональних особливостей співу і гри. Розгляд тематики і мелодики народних дум дозволив визначити індивідуальні особливості виконавства кобзарів, інтонаційні можливості діапазону співу, фактуру акомпанементу, рівень професійної майстерності бандуристів. У руслі сучасного культуротворення, висвітленню проблемних питань, що пов'язані 3 бандурним мистецтвом та частково торкаються вивчення та дослідження епічного репертуару у виконанні бандуристів, присвячені наукові розвідки О. Бобечко, С. Вишневської, В. Дутчак, І. Лісняк, К. Черемського та інших науковців. Для досягнення мети пропонованої розвідки, до наукового пошуку були також залучені праці 3 теорії музично-естетичного виховання О. Михайличенка та Л. Сбітнєвої.

Виклад основного матеріалу. Виховання підростаючого покоління для кожної народу $є$ найважливішим складником національної культури. Передача всіх культурно-історичних традицій батьків, дідів і прадідів завжди гарантувала вічність життя нації. Зауважимо, що справжнє виховання не може існувати поза традиційною культурою певного народу. Всі найвидатніші педагоги світу визнавали, що виховання дитини завжди має грунтуватися насамперед на культурно-історичних цінностях своєї нації, і лише згодом повинно відбуватися знайомство з традиціями інших народів.

Термін “музично-естетичне виховання" за останні роки глибоко вивчають у педагогічній науці. Так, О. Михайличенко пропонує таке визначення цього терміна: “музично-естетичне виховання в Україні - це діалектична взаємодія інституцій створення, накопичення і збереження досвіду національного музичного мистецтва 3 процесами передачі цього досвіду із покоління в покоління у тісному суспільно-історичному та соціально-економічному зв'язках. Разом з тим це процес передачі та засвоєння особистістю емоційно-художніх образів українського, зарубіжного музичного та суміжного з ним мистецтв, які спроможні спонукати її до творчої діяльності і створення навколо себе життя, побудованого на кращих морально-етичних цінностях, що виробило людство" $[6,145]$.

Очевидним $є$ те, що провідне місце у процесі сучасного процесу музично-естетичного виховання шкільної молоді в Україні відіграє постать учителя музики, робота якого - це музично-естетичний центр у загальноосвітній школі. Слід зауважити, що до компетенції високого рівня фахівця, безумовно, входить переосмислення історичних, культурно-національних та мистецьких процесів, а також намагання дати об'єктивну оцінку суспільним явищам, що відбувалися впродовж довгого історичного періоду утвердження української державності. 


\section{УКРАЇНСЬКІ НАРОДНІ ДУМИ В СУПРОВОДІ КОБЗИ-БАНДУРИ ЯК ДЖЕРЕЛО}

МУЗИЧНО-ЕСТЕТИЧНОГО ВИХОВАННЯПДРОСТАЮЧОГОПОКОЛІННЯ

Примітним є той факт, що українській нації притаманні художньо-емоційні риси, які відрізняють її від інших своєрідними проявами музично-естетичного характеру у повсякденному житті. Культурно-просвітницька діяльність в нашій державі грунтується на національних засадах української культури та на кращих зразках народної творчості, якими, безумовно, є епічні твори, а саме - думи, що стали неодмінною складовою музично-жанрового атрибуту кобзарства. Як відомо, термін “дума" - народного походження. Першу згадку про цей жанр пісенної творчості пов'язують з “Анналами” польського хроніста С. Сарницького, що були опубліковані 1587 року. В деяких польських віршах XVI ст. думи названі військовими псалмами, які $\epsilon$ обов'язковим атрибутом козацького життя. В історичних джерелах XVI-XVIII ст. зустрічається чимало згадок про термін “дума”. Згадані твори продовжили епічну традицію в реалістичному напрямі, відображуючи правдиві події, що пов'язані з конкретними історичними особами. Відомі сьогодні думи є жанром героїчної народнопоетичної пісенної творчості, який виник орієнтовно на рубежі XV ст., як продовження епічних традицій минулого.

За визначенням українського вченогофольклориста М. Дмитренка “українські народні думи - це епічні монументальні словесно-музичні твори героїчного, соціально-побутового характеру, що відображають модус художнього мислення козацької доби, бароко та кульмінаційний етап формування національної самосвідомості етносу, ідеї державності; мають астрофічну будову, вільний віршовий розмір (від шести до сімнадцяти і більше складів у рядку, рядки об'єднані в уступи), переважно паралельне дієслівне римування. Думи, як правило, виконують експресивним імпровізованим у межах традиції соло речитативом (мелодекламацією) - під супровід гри на кобзі або бандурі, рідше - лірі” [4, 9].

Думи, як виняткове явище української культури, що творилося й розповсюджувалося кобзарями, відіграли визначальну роль у формуванні національної свідомості українців. Яскраві представники народно-інструментального виконавства, незважаючи на всі заборони і переслідування, у всі часи пропагували загальнолюдські цінності та національні українські традиції. Їх мистецтво мало вагомий вплив на музично-естетичне навчання та виховання, адже громадська та професійна діяльність народних виконавців в усі часи була спрямована на пробудження самосвідомості українського народу, збереження та подальший розвиток його культурної спадщини, пропагування християнської віри і високої моральності, любові до людей, рідного краю, а також вимогливості до репертуару та виконавства. Мова йде, насамперед, про творчість багатьох, нажаль, невідомих кобзарів XVI - XVIII ст., а також майстерних виконавців XIX - XXст., середяких імена А. Шуга, М. Ригоренка, А. Никоненка, О. Вересая, I. КравченкаКрюковського, Г. Гончаренка, М. Кравченка, I. Кучугури-Кучеренка, Ф. Кушнерика, С. Мовчана, П. Носача, П. Гузя, Є. Адамцевича, В. Перепелюка та інших виконавців.

Відзначимо, що окрім музично-виконавського таланту, співці володіли потужнім хистом залучення слухача до художнього спілкування (комунікативна функція), вчасного інформування про непересічні події в країні (ідейно-просвітницька діяльність), формування світогляду та впливу на нього (проповідницько-виховна роль), утвердження та піднесення національного духу співвітчизників (патріотичне призначення) та, безумовно, педагогічним обдаруванням, що полягало в передачі своїх фахових знань наступникам (наставницьке функціонування)

Відомі на сьогодні думи, що переважно записані від кобзарів XIX - початку XX ст., вирізняються імпровізаційно-ре-читативним характером мелодики та передбачають сольне виконання. Як зауважила доктор мистецтвознавства В. Дутчак - “Сольна виконавська модель є найдавнішою в бандурному мистецтві, бере свій початок ще 3 часів кобзарства, спадкоємцем традицій якої і виступає сучасне бандурне мистецтво. Ї̈̈ характерними усталеними рисами були чоловічий характер співу та гри; діатонічний інструментарій (кобза, бандура); усна форма побутування та передачі досвіду; чітка жанрова ієрархія репертуару, домінуючими в якій були епічні вокально-інструментальні жанри (думи, історичні пісні, духовні псальми та канти); мандрівний характер виконавства; співтворчість музично-творчого процесу - перебування і творення виконавця-кобзаря у колі слухачів (на майдані, біля церкви, на ярмарку, на вечорницях); професійний статус кобзарів (цехові об'єднання - братства, лебійська мова, фаховий заробіток); християнська доктрина моральних і культурних цінностей” $[5,6]$.

Епічна творчість, в якій синтезувалися кращі риси національної музично-поетичної творчості, являє собою складний історичний процес, що сягає своїм корінням глибини віків. Вона відіграла величезну роль у становленні музичної культури українців. Тематика дум сукупно являючи собою оригінальний музичний літопис важливих 


\section{УКРАЇНСЬКІ НАРОДНІ ДУМИ В СУПРОВОДІ КОБЗИ-БАНДУРИ ЯК ДЖЕРЕЛО МУЗИЧНО-ЕСТЕТИЧНОГО ВИХОВАННЯ ПДРОСТАЮЧОГОПОКОЛІННЯ}

історичних подій в Україні, дістала у спадок такі визначальні риси, як побутову реалістичність, героїко-трагедійність, етико-моральність.

Тема визвольної боротьби українського народу та іiі віддзеркалення в усній народній творчості, зокрема в думах, стала предметом зацікавлення багатьох учених-фольклористів, письменників, композиторів другої половини ХІХ та XX століть. Серед них - М. Максимович, П. Житецький, I. Франко. Збиранням, дослідженням і виданням праць $з$ українського героїчного епосу займалися також М. Драгоманов, В. Антонович, П. Чубинський, М. Лисенко, М.Старицький, В. Гнатюк, Ф. Колесса, Леся Українка, Б. Грінченко, Д. Яворницький та багато інших. Вони розглядали фольклор як складову духовної культури українського народу. Особливе місце в наукових студіях над усною народною творчістю відводилося народним думам. “Як зразки, витворені відповідно до народних прагнень, тексти дум - це своєрідні художні коди реальності, що відображають історичну подію, постать або середовище, духовність нації, утверджують її оптимістичний світогляд, ідеали волі, правди, добра, любові, краси, ладу... народ естетизував своїх героїв до рангу ідеальних, зробив їх богатирями, лицарями, моральними авторитетами, гідними доброї пам'яті й наслідування" [4, 28] - читаємо у дослідженні М. Дмитренка.

Зауважимо, що побутування думового епосу розділено дослідниками на певні етапи. До раннього періоду відносять, так звані, невільницькі та думи початку козацького періоду (“Невільники на каторзі”, “Плач невольника в турецькій неволі”, “Маруся Богуславка”, “Федір Безродний”, “Самійло Кішка”, “Олексій Попович”, “Буря на Чорному морі”, “Втеча трьох братів з города Азова, з турецької неволі““, ”Три брати самарські”, “Смерть козака на долині Кодимі”, “Козак Голота”, “Хвесько Ганжа Андибер” та ін.). Виокремлюють також думи, які побутували в кульмінаційний період розвитку козаччини Гетьманщина, пізніше - Руїни (до початку XVIII ст.) ("Корсунська перемога", “Хмельницький і Барабаш”, “Богдан Хмельницький і Василь Молдавський”, “Дума про смерть Богдана Хмельницького”, “Іван Богун”, “Вдова Івана Сірка та Сірченки”, “Семен Палій і Мазепа” та ін.), а також соціальні та родинно-побутові думи (“Козацьке життя”, “Проводи козака”, “Смерть козака-бандуриста”, “Повернення сина”, “Сестра і брат”, “Удова і три сини”, “Сон удовиченка” та ін.).

Варто зазначити, що впродовж XX ст. в царині епічних жанрів відбувався процес взаємопроникнення народного та професійного мистецтва, який реалізувався в руслі пошуку сучасних, більш складніших форм і засобів виразовості. Як наслідок, з'явилися високопрофесійні стилізовані думи та балади, написані А. Кос-Анатольським, В. Камінським, Й. Яницьким, Ф. Глушком, Ф. Кучеренком, Ю. Олійником, та ін., які нарівні 3 автентичними епічними зразками стали невід’ємною складовою репертуару сучасних бандуристів-співаків $[1,105]$.

Українські народні думи належать до унікальних пам'яток не лише національної, а й світової епічної традиційної культури. Сюжети цих творів містять чіткий послідовний виклад, високу мистецьку цінність образів, вражаючі психологічні характеристики героїв різних типів. На сутності дум - як національної ознаки української народної культури ще 1892 року зауважив I. Франко: “Справді лицарським духом дихає також новий богатирський епос, який у той час, між 1560 i 1648 роками, виріс у степах запорозьких. Чудові думи про Самійла Кішку, про бурю на Чорному морі, про втечу трьох братів з Азова, про Марусю Богуславку тощо - це ті безсмертні пам'ятки ще першого етапу в розвитку козацтва, які створені генієм самого народу, і які назавжди будуть предметом гордості українського народу" [4, 9].

Використання кобзи чи бандури, як акомпануючого інструмента для виконання дум, було найбільш органічним, оскільки неголосна гра найліпше поєднувалась із поетикою епічних творів та могла, якнайповніше розкрити емоційний світ виконавців під час виступу. Однак, науковці кінця XIX початку XX століття, занотовуючи та вивчаючи традиційний репертуар кобзарів, приходили до висновку, що на відміну від пісень та легкої інструментальної музики, виконання дум вимагало доброї фахової підготовки. Завдяки проведеним розвідкам була отримана можливість відстежити шлях формування традиційного народного мистецтва, а також виявити в кобзарстві послідовне нагромадження елементів професіоналізму. Описані дослідниками кобзарські школи, які були на початках та створювалися при музичних цехах або братствах давали не лише фахові знання, а, щонайголовніше, - формували світогляд музикантів. Побудовані на грунті релігійності та духовності, вони поступово ставали “осередками виховання етичної поведінки, прививання моральних цінностей, усвідомлення національної причетності, оскільки протягом навчання, поряд із опануванням запланованого обсягу музично-поетичного матеріалу, велика увага приділялася нормам поведінки й моралі, знанням етнокультури й фольклору..." [2, 6]. Лише оволодіння 
вищезазначеними якостями давало змогу молодим кобзарям бути прийнятими до громади кобзарів та займатися виконавською i педагогічною діяльністю.

У сучасних умовах реформування освітньої галузі значна увага приділяється музичноестетичному вихованню підростаючого покоління, яке спрямоване на розширення духовного світу, формування емоційної сфери, розвиток відчуття прекрасного, вдосконалення музичного смаку. Також актуалізуються проблеми теорії і практики естетичного виховання, як одного з важливих засобів морального і розумового виховання, а також засобу формування глибоко розвиненої, духовно багатої людини.

В умовах сьогодення, ознайомлення школярів з історичними подіями та звитяжними образами, які присутні в думах, є важливим елементом музично-естетичного виховання. Розглядаючи етапи виникнення, а відтак, побутування епічних творів у супроводі кобзи-бандури, вчитель музичного мистецтва повинен спонукати школярів активно висловлювати свої думки, міркувати з приводу вчинків тих чи інших героїв та аналізувати їх. Зауважимо, що підготовча робота до сприймання дум повинна мати відмінні форми і реалізуватися за допомогою найрізноманітніших методів і прийомів навчання, а саме: слово (або лекція) вчителя; розгляд ілюстрацій та картин відомих художників (зображення кобзарів); самостійне опрацювання (вдома чи в класі) запропонованих вчителем епічних творів; прослуховування музичних зразків (аудіо та відео записи); аналіз творчих робіт учнівських малюнків на кобзарську тематику.

Основою епічного твору є сюжет, який становить собою послідовний ланцюг подій. Важлива роль належить і позасюжетним елементам - портретам, пейзажам, ліричним відступам, описам природи, інтер'єру тощо. Потрібно пам'ятати, що у кожному віці є певні особливості аналізу дум, які зумовлені рівнем підготовки учнів, адже важливим для розуміння таких творів $є$ вміння виходити за рамки сюжетної основи, розуміти авторський підтекст, який захований за фасадом подій. Тематичну канву учням збагнути не важко, але не завжди вони можуть усвідомити зв'язок сюжету 3 позасюжетними елементами, простежити ідею думи. Цей творчо-виховний процес поєднує в собі усвідомленість і емоційність, а також зближує технічне й художнє. Педагогічна діяльність стосовно опрацювання епічного репертуару повинна стати різноплановою та цілеспрямованою. 3 врахуванням можливостей учнів, вона сприятиме їх мистецькому розвитку та різнобічному музично-естетичному вихованню. Допоможе зміцнити пошану учнів до історичного минулого нашого народу.

Важливим $є$ пояснення школярам музичного супроводу думи, адже саме на уроках музики (на відміну від вивчення епічних жанрів на уроках літератури) вивчається музична сторона цього жанру, речитативна мелодика, імпровізаційна природа та творчо-виконавський характер сприйняття думи, що сприяє розвитку творчої уяви та музично-естетичного смаку учнів.

Особливо актуальними означені питання видаються в контексті того, що специфічною рисою, що характеризує сучасне українське суспільство $\epsilon$ процес поглинання молоді засобами масової культури, що “сприяє вимиванню у неї національних духовних традицій, деградації естетичних ідеалів, естетичних смаків та культурної самосвідомості'” $[7,6]$. В цьому контексті, особливо важливо прищеплювати молодій генерації високий ступінь художньої та естетичної культури, а також пропагувати вивчення еталонних зразків як вітчизняного так і зарубіжного музичного мистецтва, спираючись на позитивний національний педагогічний та музично-естетичний досвід.

Висновок. Підсумовуючи, потрібно відзначити, що музичне мистецтво є вагомим засобом становлення духовно багатої та всебічно розвиненої особистості. В цьому контексті, особливої ваги набувають уроки музики, які з поміж інших предметів шкільного навчальновиховного циклу, що мають пізнавальне та виховне спрямування, вирізняються своїм впливом на духовну культуру підростаючого покоління, а також розвиток їі музично-естетичної складової. Одним із важливих факторів, що впливає на музично-естетичне виховання особистості та $є$ дієвим засобом впливу на емоційну сферу шкільної молоді, виступає бандурне мистецтво. Основою вокально-інструментального репертуару бандуристів стали епічні твори, зокрема думи, які сягають своїм корінням глибини віків та відображають фундаментальні риси менталітету українців. Українські народні думи, що належать до унікальних пам'яток світової епічної традиційної культури, зберігають та передають традиційну культуру нашого народу, відтворюють його культурно-історичні цінності, та найкраще допомагають формуванню світогляду, високих моральних якостей, національно-патріотичних почуттів підростаючого покоління.

\section{ЛІТЕРАТУРА}

1. Бобечко О. Специфіка формування жіночого 


\section{УКРАЇНСЬКІ НАРОДНІ ДУМИ В СУПРОВОДІ КОБЗИ-БАНДУРИ ЯК ДЖЕРЕЛО МУЗИЧНО-ЕСТЕТИЧНОГО ВИХОВАННЯ ПДРОСТАЮЧОГОПОКОЛІННЯ}

сольного репертуару в бандурному виконавстві. Українська культура: минуле, сучасне, шляхи розвитку. Збірник наукових праць: наукові записки Рівненського державного гуманітарного університету. Рівне, 2016. Вип. 22. С. $103-108$.

2. Ваврик О. Кобзарські школи в Україні. Тернопіль, 2006. $221 \mathrm{c}$.

3. Вовк М. В. Основи української музичноінструментальної педагогіки: навч. посіб. ІваноФранківськ: Видавництво “Плай” ЦТТ Прикарпатського національногоуніверситетуімені Василя Стефаника, 2009. $170 \mathrm{c}$.

4. Дмитренко М. Українські народні думи як феномен традиційної культури. Українські народні думи. У 5 т. Т. 1. Думи раннього козацького періоду. [упоряд.: М.К.Дмитренко, Г. В. Довженок (тексти), С. Й. Грица (мелодії); передмови: М. К. Дмитренка, С. Й. Грици ; статті, коментарі, примітки Г.В.Довженок, А. Ю. Ясенчук, Т. М.Шевчук, О. І. Шалак, Н. М. Пазяк, І. І. Кімакович ; за заг. ред. М. К. Дмитренка, С. Й. Грици ; відп. ред. Г. А. Скрипник]. Київ, 2009. С. 6-32.

5. Дутчак В. Г. Основні тенденції в сучасному бандурному виконавстві України та української діаспори. Актуальні проблеми народноінструментального виконавства в Україні: історія і сучасність : зб. наук. пр. Рівнен. держ. гуманіт. ун-т, Ін-т мистецтв; редактор-упорядник Л. І. Горіна. Рівне, 2017. С. 6-12.

6. Михайличенко О. В. Музично-естетичне виховання дітей та молоді в Україні (друга половина XIX - початок XX ст.): Монографія. Київ, 2000. 340с.

7. Сбітнєва Л. М. Розвиток системи музичноестетичного виховання дітей і молоді в Україні (друга половина XX століття) : дис. ... доктора пед. наук : спец. 13.00.01 “Загальна педагогіка та історія педагогіки”. Східноукраїнський національний університет імені В. Даля. Київ, 2016.360 c.

\section{REFERENCES}

1. Bobechko, O. (2016). Specyfika formuvannya zhinochogo solnogo repertuaru $\mathrm{v}$ bandurnomu vykonavstvi[Specificity of the formation of women's solo repertoire in bandura performance]. Ukrainian culture: past, present, ways of development:
Collection of scientific works: scientific notes of the Rivne State Humanitarian University. Rivne, 2016. Vol. 22. pp. 103-108. [in Ukrainian].

2. Vavryk, O. (2006). Kobzarski shkoly v Ukrayini [Kobzar schools in Ukraine]. Ternopil, 221 p. [in Ukrainian].

3. Vovk, M. V. (2009). Osnovy ukrayinskoyi muzychno-instrumentalnoyi pedagogiky [Fundamentals of Ukrainian musical and instrumental pedagogy]. Teaching manual Ivano-Frankivsk: Publishing House "PLAY" CIT of the Carpathian National University named after Vasyl Stefanyk. 170 p. [in Ukrainian].

4. Dmytrenko, M. (2009). Ukrayinski narodni dumy yak fenomen tradycijnoyi kultury [Ukrainian folk dumas as a phenomenon of traditional culture]. Ukrainian folk dumas. In 5 t. T. 1. Duma of the early Cossack period. [arrangement: M. K. Dmitrenko, G. V. Dovzhenko (texts), S. Y. Gritsa (melodies); Foreword: M. K. Dmitrenko, S. Y. Gritsy; articles, comments, notes G. V. Dovzhenko, A. Yu. Yasenchuk, T.M. Shevchuk,A.I.Shalak, N.M.Pasyak,I.I.Kimakovich; for community edit M. K. Dmitrenko, S. Y. Gritsy; rep. edit G. A. Skrypnyk]. Kyiv, pp. $6-32$. [in Ukrainian].

5. Dutchak, V. G. (2017). Osnovni tendenciyi v suchasnomu bandurnomu vykonavstvi Ukrayiny ta ukrayinskoyi diaspory [The main tendencies in the modern bandura performance of Ukraine and the Ukrainian diaspora]. Actual problems of folkinstrumental performing in Ukraine: history and modern times: Sb. Sciences. Rivne Ave. state humanity Unity, Institute of Arts; editor-compiler L.I. Gorin. Rivne, pp. 6-12. [in Ukrainian].

6. Myxajlychenko, O. V. (2000). Muzychnoestetychne vyxovannya ditej ta molodi v Ukrayini (druga polovyna XIX - pochatok XX st.) [Musicalaesthetic education of children and youth in Ukraine (the second half of the nineteenth and early twentieth centuries)]. Kyiv, 340 p. [in Ukrainian].

7. Sbitnyeva, L. M. (2016). Rozvytok systemy muzychno-estetychnogo vyxovannya ditej i molodi v Ukrayini (druga polovyna XX stolittya) [Development of the system of musical and aesthetic education of children and youth in Ukraine (the second half of the twentieth century)]. Doctor's thesis. East-Ukrainian National University named after V. Dal. Kyiv. 360 p. [in Ukrainian].

Стаття надійшла до редакції 21.03.2019

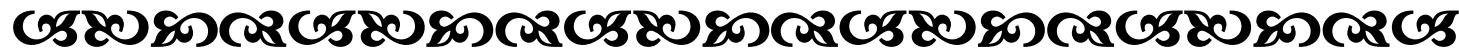

Dва основні надбання мюдської природи - це розум іміркування".

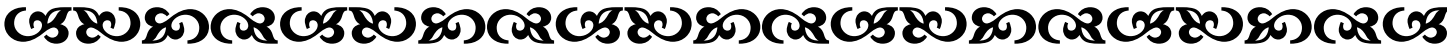

